Micron, Vol.13, No.4, pp. 467-468, 1982. Printed in Great Britain
$0047-7206 / 82 / 040467-02 \$ 03.00 / 0$

(C) 982 Pergamon Press Ltd.

\title{
PEROXISOME POPULATION PARAMETERS IN RATS FED A HIGH-FAT DIET
}

\author{
Edward J. McGuire, Robert H. Gray, John A. Lucas and Felix A. de la Iglesia
}

\author{
Department of Pathology and Experimental Toxicology \\ Warner-Lambert/Parke-Davis Pharmaceutical Research Division \\ 2800 Plymouth Rd., Ann Arbor, Ml 48105
}

Department of Environmental and Industrial Health

The University of Michigan, Ann Arbor, MI 48109

\begin{abstract}
Stereology is a useful method for critically evaluating subcellular changes evoked by pharmacological agents, thus providing a quantitative assessment of the cell under controlled conditions. Numerous factors, such as xenobiotics, diet and age $(1,2)$, affect the size and shape of subcellular organelles.
\end{abstract}

In the experiments reported here, a high-fat supplemented diet was used in the evaluation of hypolipidemic agents. Lipid-lowering agents induce profound changes in the hepatocyte cytoplasm (2). These changes include proliferation of peroxisomes, changes in the distribution of nucleated and non-nucleated peroxisomes, stimulation of lipoprotein biosynthesis and an increase in serum high density lipoproteins. In addition, hypolipidemic agents affect the distribution of cholesterol by increasing high density cholesterol and lowering low density cholesterol. For the evaluation of novel hypolipidemic agents, we developed a stereology system to study the dynamics of hepatocyte organelle changes with normal and high-lipid diets. Rats weighing $80-90$ grams were fed a diet with $5.5 \%$ peanut oil and $1.5 \%$ cholesterol for four weeks. Data included are from rats fed normal and high-fat diets with and without Clofibrate. Livers were removed and processed for electron microscopy. Electron micrographs were digitized with a Zeiss Videoplan image analyzer. Data were analyzed by a stereology program to determine various parameters of organelle population and cell size. The results are presented in Figs. 1-4. No significant changes in the number of peroxisomes per cell were seen between the normal and high-fat diet groups without drug. The stimulatory effect of Clofibrate on peroxisomes was clearly observable. A synergistic effect was observed with the high-fat diet and Clofibrate treatment. Other cellular parameters measured were not essentially different.

Previous reports (1) indicated that catalase levels increased 30 percent after feeding high-fat diets to rodents. However, no subcellular fractions of peroxisomes were examined to further characterize this biochemical observation. The divergence of results may be attributed to differences in dietary regimens, or the high-fat diet stimulating the non-particulate (soluble) catalase before reaching a measurable effect on peroxisome population. Due to the lack of quantitative electron microscopic data in their studies, a definitive correlation cannot be ascertained with their biochemical results to establish a proliferation of peroxisomes. Thus, it remains to be determined whether the increased catalase was of peroxisomal or of cytosol origin.

(1) Ishii, H. et al. (1980) Biochim. Biophys. Acta, 617, 1-11.

(2) Sternlieb, I. (1979). In H. Popper and F. Schaffiner (Eds.), Progress in Liver Disease, Vol. 6, Grune-Stratton, New York. pp 81-104.

Keywords: stereology, high-fat diet, peroxisomes, hypolipidemics. 


\begin{tabular}{|c|c|c|}
\hline \multicolumn{3}{|c|}{ CELL PARAMETERS (MEAN \pm SE) } \\
\hline Diet/Treatment & $\begin{array}{l}\text { Population } \\
\left(\mathrm{n} \cdot 10^{6} / \mathrm{g}\right)\end{array}$ & $\begin{array}{l}\text { Volume } \\
\left(u^{3}\right)\end{array}$ \\
\hline Normal Diet & $181+16$ & $5731+550$ \\
\hline $\begin{array}{l}\text { Normal Diet/ } \\
\text { Clofibrate }\end{array}$ & $165 \pm 12$ & $6154 \pm 386$ \\
\hline High-Fat Diet & $191+6$ & $5448+153$ \\
\hline $\begin{array}{l}\text { High-Fat Diet/ } \\
\text { Clofibrate }\end{array}$ & $214+11$ & $4613+240$ \\
\hline
\end{tabular}

\begin{tabular}{|c|c|c|c|}
\hline \multicolumn{4}{|c|}{ PEROXISOME PARAMETERS (MEAN \pm SE) } \\
\hline Diet/Treatment & $\begin{array}{c}\text { Population } \\
(\mathrm{n} / \mathrm{cell})\end{array}$ & $\begin{array}{c}\text { Volume } \\
\left(\mathrm{mu}^{3} / \mathrm{cel} 1 \mathrm{l}\right) \\
\end{array}$ & $\begin{array}{c}\text { Diameter } \\
\text { (u) }\end{array}$ \\
\hline Normal Diet & $1280+122$ & $88+8$ & $0.52 \pm 0.01$ \\
\hline $\begin{array}{l}\text { Normal Diet/ } \\
\text { Clofibrate }\end{array}$ & $2661 \pm 307$ & $208+21$ & $0.53+0.01$ \\
\hline High-Fat Diet & $1099 \pm 86$ & $75 \pm 4$ & $0.51 \pm 0.01$ \\
\hline $\begin{array}{l}\text { High-Fat Diet/ } \\
\text { Clofibrate }\end{array}$ & $3739+401$ & $248+41$ & $0.49 \pm 0.01$ \\
\hline
\end{tabular}
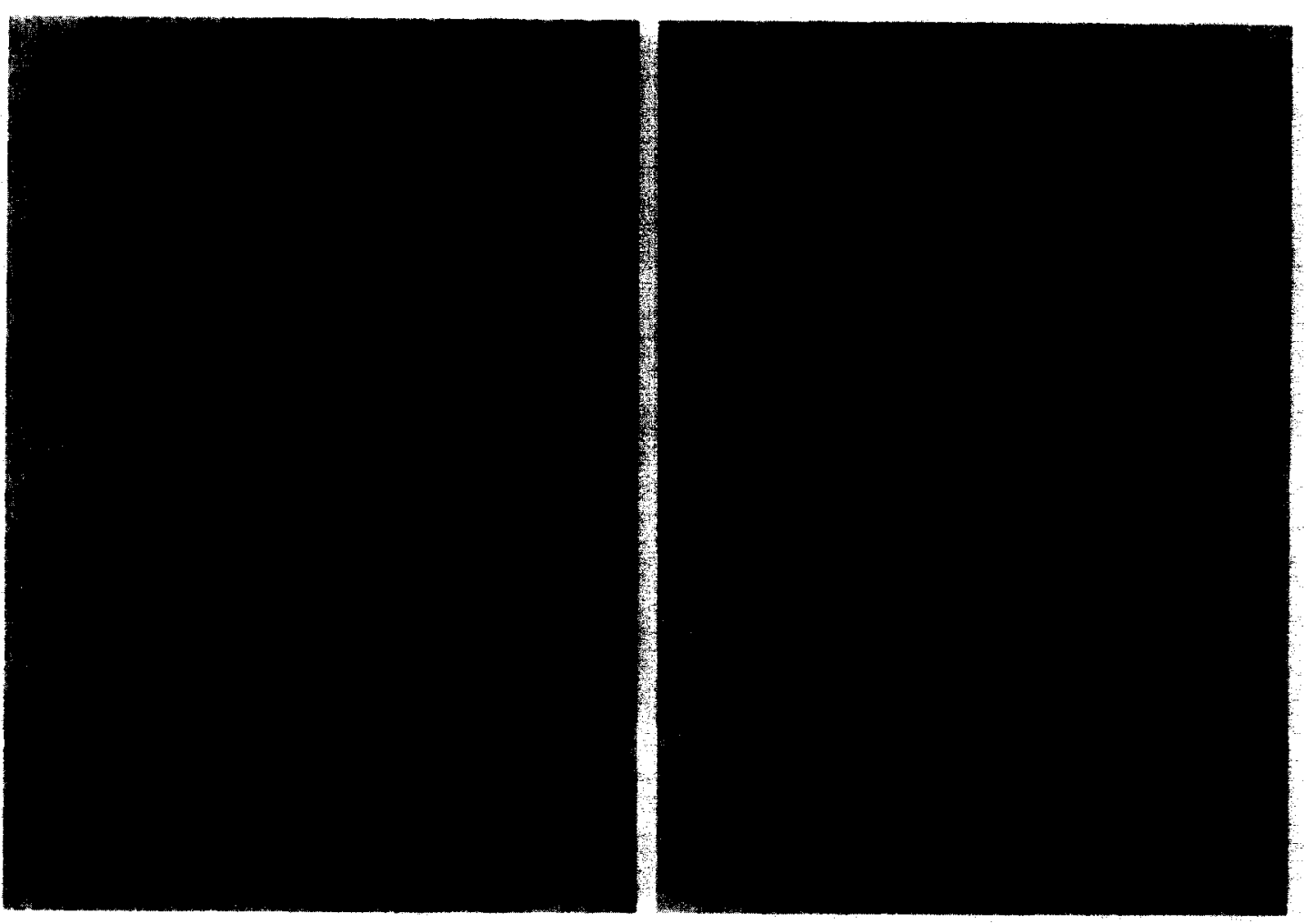

Fig. 1. Cell populations and associated volumes.

Fig. 2. Population, volume and diameter of peroxisomes.

Fig. 3. Electron micrograph of liver from male rat maintained on normal diet.

Fig. 4. Electron micrograph of liver from male rat given $100 \mathrm{mg}$ Clofibrate/kg of body weight, daily for one month ( $\mathrm{P}$ - Peroxisome, M - mitochondria, N - nucleus). 